\title{
QUALITY EVALUATION OF NATURALLY FERMENTED ALCOHOLIC BEVERAGES, MICROBIOLOGICAL EXAMINATION OF SOURCE OF FERMENTATION AND ETHANOL PRODUCTIVITY OF THE ISOLATES
}

\author{
V. K. JOSHI, ${ }^{\text {a,c }}$ and D. K. SANDHU ${ }^{b}$ \\ ${ }^{a}$ Department of Postharvest Technology, Dr YS Parmar \\ University of Horticulture \& Forestry, Nauni-Solan (H.P.) 173 230. India \\ ${ }^{b}$ Department of Microbiology, Guru Nanak Dev University, Amritsar $(\mathrm{Pb}$.). India
}

(Received: 15 November 1999; accepted: 14 June 2000)

\begin{abstract}
The naturally fermented alcoholic (NFA) beverages collected from tribal areas contained higher quantity of methanol, with wide variations in ethanol, $\mathrm{pH}$ and volatile acidity. The NFA beverages were also found to be contaminated with Brettanomyces spp. and coliform bacteria indicating a potential danger of their consumption. The examination of natural sources of fermentation (NSF), frequently used in such fermentations, revealed the presence of fungi viz., Aspergillus flavus, Aspergillus oryzae, Mucor spp., Rhizopus spp.: the yeast included Saccharomyces spp., Scytalidium thermophilus (Torula) and Rhodotorula and bacteria viz., Pediococcus, Leuconostoc and Pseudomonas. Except for a few, the general ethanol productivity of the isolates from NSF was low. Saccharomyces spp. had higher population and was predominant among the yeasts isolated from NSF. The abnormal characteristics of the NFA beverages could be correlated with the raw materials, source and method of fermentation and distillation. Use of pure yeast and proper distillation method could improve the quality of such beverages.
\end{abstract}

Keywords: alcoholic beverages, methanol, natural sources of fermentation, Saccharomyces, quality

In some tribal areas of India including Himachal Pradesh, preparation of customary alcoholic beverages and their comsumption are permitted at home. In preparation of such beverages, natural source of microflora is employed as a fermenting agent, using locally available raw materials such as ragi, apricot, apple. In this communication such beverages have been described as naturally fermented alcoholic (NFA) beverages. Due to lack of proper scientific technology many a times, the quality of such beverages is uncertain and their comsumption leads to higher incidence of fatal

${ }^{\mathrm{c}}$ To whom the correspondence should be addressed 
diseases among the consumers (SHARMA, 1986). Presence of some compounds besides effecting the quality makes the NFA beverages toxic. Among the toxic compounds in alcoholic beverages is methanol which occurs in wines and brandies also, ranging from 32 to $238 \mathrm{mg} \mathrm{l}^{-1}$ in grape wine, $410-700 \mathrm{mg} \mathrm{l}^{-1}$ in French Cognac, $180-500 \mathrm{mg} \mathrm{l}^{-1}$ in Spanish distillates, $390-920 \mathrm{mg} \mathrm{l}^{-1}$ in German distillates, $1200 \mathrm{~g} \mathrm{hl}^{-1}$ in plum, $59 \mathrm{~g} \mathrm{hl}^{-1}$ in cognac, $700 \mathrm{~g} \mathrm{hl}^{-1}$ in pear (Lisle et al., 1978; POSTEL \& ADAM, 1979; 1980). A number of factors influence the methanol content in grape wine (AMERINE et al., 1980; HARJAVEC, 1990; KANA et al., 1991). Before attempting to improve the quality of NFA beverages, their chemical and microbiological examination including the methanol content would be a pre-requisite.

Among the most important factors affecting the quality of fermented products is the method of preparation and the microorganisms involved in the fermentation process. However, there is no scientifically documented report describing the method of preparation, characteristics of such alcoholic beverages and involvement of microflora except for the scattered reports on home scale wine fermentation from dates (ALI \& DIRAR, 1984), yeasts involved in spontaneous fermentation (ABRAMOV et al., 1990) and a survey of beer (GREENSHIELDS, 1974). A comprehensive knowledge of the microflora involved can lead to better understanding of the fermentation process so as to improve the same. These considerations led us to evaluate NFA beverages for chemical and microbiological qualities vis-a-vis experimental products, examination of source of fermentation and ethanol productivity of the microorganisms involved in the source of fermentations (NSF).

\section{Materials and methods}

\subsection{Naturally fermented alcoholic beverages}

Twenty-two samples of naturally fermented alcoholic (NFA) beverages produced in the tribal district Kinnaur of Himachal Pradesh (India) were collected. The beverages included both distilled and non-distilled, prepared from fruits, jaggery and cereals or their combinations. Details of type of samples and their numbers were as follows: naturally fermented wine 6 samples, naturally fermented distillate 6 samples, naturally fermented cereal products 6 samples, naturally fermented cereal distillates 4 samples. About $100 \mathrm{ml}$ of each sample was taken in a sterile plastic bottle and particulars of the samples were noted. 


\subsection{Experimental wines and brandies}

For comparison, wines from apple, plum, pear and fruit-honey were prepared according to the standard procedure (AMERINE et al., 1980; JOSHI et al., 1990; JOSHI \& BHUTANI, 1991; JOSHI, 1997). The apple and citrus pomaces were also fermented and distilled. Three samples, each of the fermented apple and citrus pomace extract and their distillates were analysed. Wine from wild apricot fruits used very frequently in these areas was prepared as per the methods reported earlier (JOSHI et al., 1990). The juices from apple and pear were fermented while in case of plum and apricot the pulps were used for fermentation to produce the wine. Standard wine yeast Saccharomyces cerevisiae (UCD 595) was employed to conduct the fermentation. As per the standard practice, the temperature of fermentation was kept at $22 \pm 1{ }^{\circ} \mathrm{C}$. The wines from apple and wild apricot were distilled, cutting head and tails and retaining the middle fraction or heart. The number of samples used for the study for cider were 10 , plum 8 , fruit-honey wine 6 , apricot wine 4, pear wine 3 and apple wine 3 . Wild apricot and apple brandies were 6 each.

\subsection{Examination of source of fermentation}

The material used as a source of fermentation/inoculum commonly in the preparation of such beverages was also collected. The natural sources of fermentation (NSF) used by local tribes were analysed for total microbial count using the pour plate technique (HARRIGAN \& MCCANCE, 1966). Two morphologically different samples of the material employed to conduct such fermentation were taken and marked as SN1 and SN2. The predominant microflora in each source was also determined. The yeast count was made on yeast malt extract agar (YMEA), the fungal count on potato dextrose agar (PDA) while the bacterial population was estimated on standard plate count (SPC) agar. The confirmation of coliform bacteria was made on eosine methylene blue agar (EMBA) as per the standard methods. The plates were incubated at $28 \pm 1{ }^{\circ} \mathrm{C}$ for $48-72 \mathrm{~h}$ for yeasts and fungi, and $37 \pm 1{ }^{\circ} \mathrm{C}$ for $48 \mathrm{~h}$ for bacteria as per the standard procedure. After the incubation, the counts were taken and expressed as colony forming unit (CFU $\mathrm{g}^{-1}$ ). Preliminary identification of the isolates was made using the morphological and biochemical tests, as prescribed after isolating the typical colonies (HARRIGAN \& MCCANCE, 1966).

\subsection{Ethanol productivity}

The yeast and bacterial isolates were screened for ethanol productivity by inoculating a loopful of the respective growth from the slant in glucose malt extract broth (GMEB) having $2.5 \%$ glucose, $1.0 \%$ malt extract, $0.5 \%$ sodium chloride, with $\mathrm{pH}$ 5.4. Sterilized glucose solution was added separately. Incubation was done for $48 \mathrm{~h}$ at 
$30 \pm 1{ }^{\circ} \mathrm{C}$. Ethanol content in the filtrate was determined by gas chromatographic procedure as described for methanol under 1.5.

\subsection{Analysis of naturally fermented alcoholic beverages}

The samples of naturally fermented alcoholic beverages were analysed for methanol, $\mathrm{pH}$, volatile acidity and titratable acidity as per the standard methods (AMERINE et al., 1980). Methanol was estimated by gas chromatography, using FID detector, flow rate of $30 \mathrm{ml} \mathrm{min}-1 \mathrm{~N}_{2}, 130{ }^{\circ} \mathrm{C}$ and $220^{\circ} \mathrm{C}$ as column and injection temperatures, respectively. The analyses were performed after calibrating the instrument with standard ethanol and methanol solution. The procedure was standardized after separating ethanol and methanol peaks in GLC determination. Ethanol content in the distilled beverages was determined using an alcoholometer while that of fermented nondistillate beverages was estimated by the potassium dichromate colorimetric method of CAPUTI and co-workers (1968). The microbiological quality of the naturally fermented alcoholic beverages was estimated by standard plate count as per the standard procedure. Appropriate dilution of the samples were employed for this purpose and count were expressed as CFU $1 \mathrm{ml}^{-1}$.

\section{Results and discussion}

\subsection{Evaluation of naturally fermented beverages}

2.1.1. Methanol content. The data (Table 1) showed appreciable differences among various types of the beverages for methanol content. It is clear that though on the basis of types of raw materials 4 categories could be made as given in Table 1 yet in the group itself a very large variation can be observed as indicated by very large values of SD. It is expected since the samples were taken from different sources and their number was comparatively small to make a homogenous population. Based on the mean values, the fermented pomace contained the highest while experimental wines as a group had the lowest concentration of methanol. Low values of SD reflect that these products were made using the same technique representing comparatively homogenous population. In comparison to the experimental wines, NFA beverages had 14 times more methanol. Similarly, the distilled liquors prepared from the NFA beverages in the tribal areas contained about 40 times more methanol than their experimental counterparts. However, the cereal based NFA beverages, irrespective of being distilled or not, had considerably lower methyl alcohol than the corresponding fruit based beverages. All the experimental fruit wines contained less than $200 \mu 11^{-1}$ of mean methanol content. But plum and apricot wines had higher concentration than the other wines. 
Table 1

Methanol content $\left(\mu \mathrm{l}^{-1}\right)$ in different types of alcoholic beverages

\begin{tabular}{|c|c|c|}
\hline Type of alcoholic beverage & & $\begin{array}{c}\text { Mean } \pm \text { S.D. } \\
(n-1)\end{array}$ \\
\hline \multicolumn{3}{|l|}{ A Naturally fermented alcoholic beverages } \\
\hline Naturally fermented wines & & $772 \pm 156.4$ \\
\hline Naturally fermented distillates & & $4414 \pm 2463.0$ \\
\hline Naturally fermented cereal products & & $206 \pm 223.6$ \\
\hline \multirow[t]{2}{*}{ Naturally fermented cereal distillates } & & $448 \pm 599.7$ \\
\hline & mean & 1460 \\
\hline \multicolumn{3}{|l|}{ B Experimental fruit wines } \\
\hline Cider & & $90 \pm 2.58$ \\
\hline Plum wine & & $192 \pm 29.25$ \\
\hline Fruit-honey wines & & $25 \pm 8.24$ \\
\hline Apricot wine & & $168 \pm 28.56$ \\
\hline Pear wine & & $55 \pm 5.00$ \\
\hline \multirow[t]{2}{*}{ Apple wine } & & $100 \pm 17.32$ \\
\hline & mean & 105 \\
\hline \multicolumn{3}{|l|}{ C Experimental brandies } \\
\hline Wild apricot (chuli) brandy & & $136 \pm 58.60$ \\
\hline \multirow[t]{2}{*}{ Apple brandy } & & $108 \pm 17.06$ \\
\hline & mean & 122 \\
\hline \multicolumn{3}{|l|}{ D Pomace based fermented products } \\
\hline Fermented apple pomace extract & & $1141 \pm 14.50$ \\
\hline Fermented citrus pomace extract & & $1220 \pm 42.72$ \\
\hline Fermented apple pomace distillate & & $7303 \pm 61.02$ \\
\hline \multirow[t]{2}{*}{ Fermented citrus pomace distillate } & & $9450 \pm 39.39$ \\
\hline & mean & 4788 \\
\hline
\end{tabular}

S.D.: n-1 standard deviation

2.1.2. Ethanol and volatile acidity. Quite a large variation among the samples of NFA beverages for ethanol, volatile acidity and $\mathrm{pH}$ were also noted (Table 2). NFA (distilled) beverages contained as high as 55 per cent and as low as 7.5 per cent ethanol. Compared to the experimental wines and brandies, these NFA beverages do not fall in any of the categories. A comparison of ethanol, volatile acidity and $\mathrm{pH}$ values of different NFA beverages with those of experimental products (Table 3) show that some of the NFA samples had ethanol content higher than commercially distilled liquors, 
many had more than fortified wines, while a few had this value comparable to a table wine or cider. The very low ethanol content in non-distilled NFA beverages is expected but not in the distilled NFA beverages where it indicates faulty method of fermentation and/or distillation. Nearly 80 per cent of the total samples of NFA had volatile acidity of more than 0.04 per cent (AMERINE et al., 1980), which is a legal limit for fruit wines. The concentration of volatile acid in NFA is too high for any sound alcoholic beverage as revealed by the values of Table 2 and Table 3. High volatile acidity indicates the occurrence of acetification after the completing of alcoholic fermentation.

Table 2

Range of ethanol, volatile acidity and $p H$ of naturally fermented alcoholic beverages

\begin{tabular}{|c|c|}
\hline Parameters & No. of samples ${ }^{\mathrm{a}}$ \\
\hline \multicolumn{2}{|l|}{ Ethanol (\%v/v) } \\
\hline Below 10 & $1(4.5)$ \\
\hline $10-20$ & $7(31.8)$ \\
\hline $20-30$ & $6(27.2)$ \\
\hline $40-60$ & $8(36.6)$ \\
\hline \multicolumn{2}{|c|}{ Volatile acidity ( $\%$ acetic acid) } \\
\hline Below 0.04 & $4(18.2)$ \\
\hline 0.04 to 0.10 & $8(36.6)$ \\
\hline 0.10 to 0.40 & $10(45.5)$ \\
\hline \multicolumn{2}{|l|}{$\mathrm{pH}$} \\
\hline Below 4 & $8(36.6)$ \\
\hline 4 to 4.5 & $5(22.2)$ \\
\hline 4.5 to 5.0 & $5(22.2)$ \\
\hline Above 5 & $4(19.2)$ \\
\hline
\end{tabular}

Values in parentheses indicate percentage

${ }^{\mathrm{a}}$ Total number of samples $=22$

2.1.3. Microbiological quality. Out of 22 samples of NFA beverages collected, 4 (18.2\%) were found to be positive for microbial contamination showing standard plate count (SPC) ranging from 10 to $3 \times 10^{4} \mathrm{CFU} \mathrm{ml}^{-1}$. All these samples showed the presence of bacteria except one which had yeast almost in pure culture. The bacteria belonged to the coliform group, while the yeast was identified as belonging to Brettanomyces spp. 
Table 3

Ethanol, volatile acidity and $p H$ of the experimental alcoholic beverages

\begin{tabular}{lrcc}
\hline Parameters & $\begin{array}{c}\text { Ethanol } \\
(\% \mathrm{v} / \mathrm{v})\end{array}$ & $\begin{array}{c}\text { Volatile } \\
\text { acidity } \\
(\% \mathrm{AA})\end{array}$ & $\mathrm{pH}$ \\
\hline Cider & $4.85 \pm 0.5$ & $0.032 \pm 0.001$ & $3.74 \pm 0.002$ \\
Plum wine & $10.50 \pm 0.7$ & $0.024 \pm 0.007$ & $3.31 \pm 0.004$ \\
Fruit-honey wines & $8.30 \pm 1.0$ & $0.035 \pm 0.002$ & $3.40 \pm 0.01$ \\
Apricot wine & $10.17 \pm 0.3$ & $0.037 \pm 0.001$ & $3.66 \pm 0.05$ \\
Pear wine & $10.80 \pm 0.5$ & $0.04 \pm 0.001$ & $3.99 \pm 0.001$ \\
Apple wine & $9.80 \pm 0.1$ & $0.035 \pm 0.001$ & $3.74 \pm 0.01$ \\
Apricot brandy & $42.00 \pm 0.1$ & $0.048 \pm 0.006$ & $4.98 \pm 0.02$ \\
Apple brandy & $42.00 \pm 0.1$ & $0.03 \pm 0.001$ & $4.68 \pm 0.02$ \\
\hline
\end{tabular}

Means $\pm \mathrm{n}-1$ standard deviation; AA: acetic acid

\subsection{Microbiological examination of natural sources of fermentation}

The data (Table 4) revealed the presence of yeast, bacteria and fungi in both the samples of natural source of fermentation (NSF). It is clear that SN1 had higher population of microorganism with higher count of yeast than SN2. Among the fungi, Aspergillus flavus, Aspergillus oryzae, Mucor spp. and Rhizopus spp. in order of decreasing occurrence were recorded. Amongst the yeasts, Saccharomyces spp. was predominant followed by Scytalidium thermophilus (Torula) and Rhodotorula. Among the bacteria, Pediococcus, Leuconostoc and Pseudomonas fluorescens were isolated.

Table 4

Microbiological profile of natural sources of fermentation used by the tribals

\begin{tabular}{lccc}
\hline & \multicolumn{3}{c}{ Log colony forming unit $\left(\mathrm{CFU} \mathrm{g}^{-1}\right)$} \\
\cline { 2 - 4 } Sample type & Bacteria & Yeasts & Fungi \\
\hline Natural source 1 (SN1) & 2.47 & 6.30 & 3.02 \\
Natural source 2 (SN2) & 2.69 & 3.69 & 3.60 \\
\hline
\end{tabular}


Table 5

Type of predominant microorganisms in natural source of fermentation

\begin{tabular}{ll}
\hline Microorganism & Predominant types \\
\hline Fungi & Aspergillus flavus \\
& Aspergillus oryzae \\
& Mucor spp. \\
& Rhizopus spp. \\
& Saccharomyces spp. \\
Yeasts & Shtalidium thermophilus (Torula spp.) \\
& Phodorula spp. \\
& Pediococcus spp. \\
Bacteria & Leuconostoc spp. \\
& Pseudomonas flourescens \\
\hline
\end{tabular}

\subsection{Ethanol productivity}

The results on ethanol productivity of the isolates (Fig. 1) showed that only a few isolates $(\mathrm{N} / 4, \mathrm{~N} / 6, \mathrm{~N} / 8, \mathrm{M} / 6, \mathrm{M} / 7, \mathrm{M} / 8$ and $\mathrm{Y} / 8)$ had appreciable ethanol productivity while the majority of these did not show either any ethanol productivity or it was very low. Out of these isolates, $\mathrm{N} / 4, \mathrm{M} / 7 \mathrm{M} / 8$ and $\mathrm{Y} / 8$ showed the maximum ethanol productivity. Their identification revealed that all the ethanol producing isolates were yeasts belonging to Saccharomyces spp., while low ethanol producing isolates were bacteria or low ethanol producing yeasts like Rhodotorula.

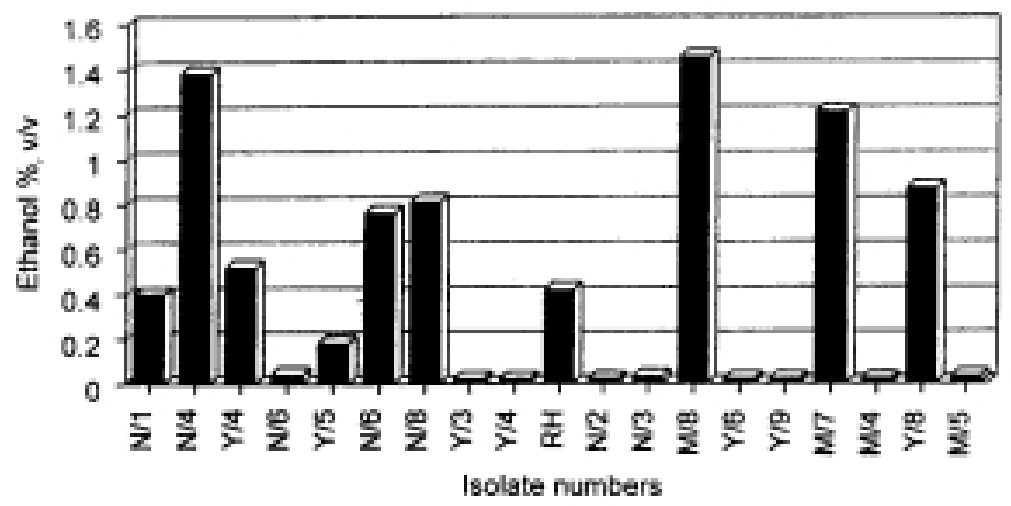

Fig. 1. Ethanol productivity of various isolates from natural sources of fermentation 


\section{Discussion}

The higher methanol content recorded in NFA beverages could be attributed to the activity of mixed natural microflora including fungi and bacteria involved in such fermentations, since the yeasts do not per se produce methanol during the wine fermentation (LEE et al., 1975). Further, methanol contents of the fruit wines and brandies prepared experimentally in our study were found to be comparable to that of the grape wine. The presence of low quantity of methanol (among other volatiles) in home brewed date and grape wine is not unusual. Thus, the use of the pectolytic enzymes added or that of native fruits used as a raw material (ALI \& DIRAR, 1984; BERTUCCIOLI \& VIANI, 1976) might have also contributed to the higher methanol contents in NFA beverages. The fungi isolated from NSF are known to be good sources of enzymes including pectinolytic ones (FRAZIER, 1971), which might have facilitated the production of methanol by hydrolysis of pectin content in NFA beverages, and in the fermented pomaces and their distillates as in our study. Observations on pomace and their distillates are in confirmation to those reported earlier (JAROSZ, 1988).

Methanol content is also known to be affected by the distillation method (AMERINE et al., 1980). Uncut piedmont pomace brandies and the fruit brandies contained more methanol content than grape brandies (PÁNDI \& BIKFALVI, 1989), which in the latter case must have originated from the $\mathrm{HCN}$ derived from amygdalin. Apparently, the reduction in methanol contents in the experimental brandies than the distillates from NFA beverages in our studies is clearly the result of the method of distillation where heads and tails are discarded (AMERINE et al., 1980).

Large variations in the ethanol contents of the NFA beverages alongwith far greater volatile acidities than prescribed (AMERINE et al., 1980) indicate lack of standardized technology in the production of alcoholic beverages as has also been observed earlier for 'Pisco' - a South American drink (HERRAIZ et al., 1990). The higher volatile acidity in NFA beverages might be the result of mixed microbial fermentation and aerobic mode of alcoholic fermentation as observed in tea cider fermentation (INDRATI \& OHTA, 1990), coupled with lack of any preservative technique resulting in oxidation of ethanol to acetic acid as the former has preservative effect only above 15 per cent (FRAZIER, 1971). Presence of coliform bacteria in the NFA beverages also point out the unhygienic conditions practised in the preparation of such beverages in the tribal areas as observed in an earlier survey, too (GREENSHIELDS, 1974). The low $\mathrm{pH}$ of NFA beverages, however, might have prevented the growth of any pathogenic microorganism in wines.

The occurrence of fungi, yeasts and bacteria in the NSF is not strange, as in the absence of any preservative, microorganism present on the surface of fruits, sugar or flowers etc. used very frequently to initiate such fermentations. Earlier yeasts and/or 
bacteria have also been isolated from the traditionally fermented Indonesian tea cider and fermented apple (INDRATI \& OHTA, 1990; EthIRAJ et al., 1980). Source of inoculum at home scale fermentations has been traceable to dates, spices and sorghum. Torulopsis, Saccharomyces, lactic acid bacteria viz. Leuconostoc, Lactobacillus, Streptococcus as well as Acetobacter, Gluconobacter, Bacillus and Klebsiella were also identified but these were not encountered in our studies (ALI \& DIRAR, 1984).

It is quite apparent from these results that the yeasts such as Saccharomyces spp. played an important role alongwith bacteria and molds in the fermentation process practised in the tribal area, resulting in the production of ethanol. But low ethanol yield recorded in some of the NFA beverages in our studies is attributable to the low population of the high ethanol producing microorganism or the involvement of different yeasts species (OJMO, 1991) converting a part of sugar to metabolites other than ethanol (INDRATI \& OHTA, 1990) and/or secretion of killer toxin by the wild yeasts (RADLER et al., 1990).

The higher methanol content in NFA beverages or home brewed beverages is of great concern due to its toxicity causing suspected bowel ulceration, blindness or death although the lethal properties of some of these country made wines are legendary (FOWLES, 1989). It would underline the need for caution but not undue fears as the human body can metabolize $340 \mathrm{mg} \mathrm{kg}^{-1}$ of body weight of methanol compared to $1400 \mathrm{mg} \mathrm{kg}^{-1}$ body weight of ethanol (ChriStENSEN, 1973). Nevertheless, the wine should have methanol content as low as possible from total safety considerations. For this, the use of pure culture of wine yeasts i.e. Saccharomyces cerevisiae rather than mixed bacterial and yeast fermentation carried out by NSF need to be encouraged as concluded by TINI and co-workers (1990), distillation practice where head and tail are cut-off, manipulation of conditions of wine fermentation (HERRAIZ et al. 1989) and sequential use of yeast culture (TOLEDONO et al., 1991) should be practised.

\section{Conclusions}

Based on the results, it can be concluded that:

- Naturally fermented alcoholic beverages have several undesirable quality characteristics

- Source of fermentation shows the involvement of fungi, yeasts and bacteria

- The quality of such beverage could be improved by following the standard practices of wine making i.e. addition of pure culture of yeast, addition of preservative like potassium metabisulphite, etc.

- Using the proper distillation technique where head and tail are removed, is essential to produce quality liquor. 


\section{References}

Abramov, S. A., KOTEnKO, S. T., VlaSOve, O. K. \& ISAEVA, D. S. (1990): New yeast strain. Pisheahvaya Prom., USSR, 2, 46-47 -ref: FSTA, 23(11) 11H78 (1991).

ALI, M. Z. \& DIDAR, H. A. (1984): Microbiological study of Sudanese date wines. J. Fd. Sci., 49, 459-460.

Amerine, M. A., BerG, H. W., KunkeE, R. E., Ough, E. S. Singleton, V. L. \& WeBB, A. D. (1980): The technology of wine making. 4th ed. AVI Publishing Co., Inc. Westport, CT, pp. 77-243, 523-547, 731-768.

BERTUCCIOLI, M. \& VIANI, R. (1976): Red wine aroma: Identification of head-space constituents. J. Sci. $F d$. Agric., 11, 38-41.

CAPUTI, A., UEDA, M. Jr, \& BROWN, J. (1968): Spectrophotometeric determination of ethanol in wine. Am. J. Enol. Vitic., 19, 160-165.

CHRISTENSEN, H. E. (1973): The toxic substances. List Natl. Inst. for Occupational Safety and Health, Washington, D. C., p. 534

ETHIRAJ, S., ONKARYYA, H. \& SURESH, E. R. (1980): Nature and sequence of yeast during fermentation of apple grown in India. J. appl. Bacteriol., 48, 97-100.

FOWLES, G. (1989): The complete home wine maker. New Scientist, Sept issue, 38-42.

FRAZIER, W. C. (1971): Food microbiology. Tata Mc Graw Hill Publ Co., New Delhi, pp. 371-431.

GREENSHIELDS, R. N. (1974): Volatile in home brewed beers and wines. J. Sci. Fd. Agric., 25, 1307-1312.

HARJAVEC, S. (1990): Effect of grape harvest method on methanol content of white wines. Agronomiski Glasnik, 52(1/2), 21-30, -ref.: FSTA 23 (10) 10 H 46, 1991.

HARRIGAN, H. F. \& MCCANCE, E. M. (1966): Laboratory methods in microbiology. Academic Press, London, p.7-229.

Herraiz, T., MARTinalvarez, P. J., REGlero, G. \& CABEZUDO, M. D. (1989): Differences between wines fermented with and without sulphur dioxide using selected yeasts. J. Sci. Fd. Agric., 49, 249-258.

Herraiz, T., Regleró, G., Herraiz, M., MartinalvareZ, P. J. \& CabezUdo, M. D. (1990): The influence of the yeast and type of culture on the volatile composition of wines fermented without sulphur dioxide. Am. J. Enol. Vitic., 41, 313-318.

INDRATI, R. \& OHTA, Y. (1990). Microbiological and chemical changes in Indonesian Tea Cider fermentation. J. Fac. Appl. Biol. Sci., 29, 1-9.

JAROSZ, K. (1988) Solid state fermentation of apple pomace. Acta Alimentaria Polonica, 16, 139-144.

JOSHI, V. K. (1997): Fruits wines. Directorate of Extension Education, Dr YS Parmar University of Horticulture \& Forestry, Nauni, Solan (H. P) India, p. 255.

JOSHI, V. K. \& BHUTANI, V. P. (1991): The influence of enzymatic clarification on the fermentation behaviour, composition and the sensory qualities of apple wine. Sci. Aliments, 11, 491-496.

JOSHI, V. K., BHUTANI, V. P. \& SHARMA, R. C. (1990): Effect of dilution and addition of nitrogen source on chemical, mineral and sensory qualities of wild apricot wine. Am. J. Enol. Vitic, 41, 229-231.

Kana, K., Kaneliaki, M., PAPAdimitrio \& KoutinaS, A. A. (1991): Causes of and methods to reduce methanol content of Tsi coudia, Tsipouro and Quzo. Int. J. Fd. Sci. Technol., 26, 241-247.

LeE, C. Y., ROBInSON, W. R., VAN BuREN, J. P., ACREE, T. E. \& STUEWS, G. S. (1975): Methanol in wines in relation to processing and variety. Am. J. Enol. Vitic, 26, 184-187.

LISLE, D. B., RICHARDS, C. P. \& WARDLEWORTH (1978): The identification of distilled alcoholic beverages. J. Inst. Brew., 84, 93-96.

OJMO, E. E. (1991): Yeast flora of Nifor palm Sapa. Tropical Agriculture, 68, 381-383.

PÁNDI, F. \& BIKFALVI, I. (1989): Szeszes italok minőségét meghatározó összetevők és azok kialakulásának kémiai, fizikai, mikrobiológiai folyamatai. (Components determining the quality of alcoholic drinks 
and chemical, physical and microbiological changes during their development). Szeszipar, 4, $131-138$.

POSTEL, W. \& ADAM, L. (1979): Gas chromatographic characterization of brandy cognac and Armagnac I Study of methods, Branntweinwirtschaft, 2, 404-409.

POSTEL, W. \& ADAM, L. (1980): Gas chromatographic characterization of brandy, Cognac and Armagnac II. Content of volatile substances. Branntweinwirtschaft, 3, 154-164.

RADLER, F., SCHMITT, M. J. \& MEYER, B. (1990): Killer toxin of Hansenspora uvarum. Archives Microbiol., $154,175-178$

SHARMA, P. C. (1986): Home wine making. Govt of H. P. Publication (H. P.) Shimla - India.

TINI, V., CARIDI, A. \& ROMANO, P. (1990). Yeasts of Calabrian wines, study and selection. Industrie delle Bevande, 19, 24-27.

Toledano, F.; MORENO, J., ORTEGA, J. M. \& MedinA, M. (1991) Sequential use of two yeasts for fermentation of musts for sherries. Cerevisiae Biotechnol., 16, 35-41. 